\title{
THE DOCTRINE OF CONCEALMENT: A REMNANT IN THE LAW OF INSURANCE
}

\author{
Bertram Harnett* \\ I \\ A Test Is INTroduced
}

The average person holding an insurance policy is unsophisticated in the law, and meets the everyday challenges of life passably serene in the knowledge that his insurance policy represents financial indemnity from the fortuitous unhappinesses which are somehow part of living. Whether his policy be of life insurance, fire insurance, theft insurance, or any of the countless varieties of business and personal insurance issued, it would come as a shock for him to know that his instrument of security can be in jeopardy because he failed to disclose any number of facts to his insurer.

This is the doctrine of concealment; unknown to most laymen, obscure to many insurance agents and brokers. Even though the insurance company asked no questions when it issued the policy, or even though the insured filled out an application stating all he knew, the insurance company may be able to escape ultimate liability on the grounds that the insured did not first tell it something that it thought he should have.

This surprising doctrine strikes hard at the vitals of an insurance-buying society, the members of which procure insurance to gain a security, an assurance that misfortune will not be financial disaster. A doctrine which has the effect of gnawing at these expectations must be able to justify itself convincingly. History and judicial veneration are not enough; the doctrine must be tested in social utility and, if the result is negative, cast swiftly aside. This is a test of the doctrine of concealment; the result is negative.

II

\section{The Doctrine of Concestament in Perspective}

\section{A. The Selection of Risks}

At the heart of successful insurance underwriting is the ability to select and control risks, since the general goal is to make the premium charged commensurate with the risk. The business of insurance is dependent upon the receipt of sufficient premi-

- A.B. 1943, Brooklyn College; LL.B. 1948, Columbia University. Formerly Visiting Assistant Professor of Insurance Law, University of Kansas. Formerly Associate in Law, Columbia University. Member of the New York Bar Association. Contributor to Practicing Law Institute Series on Fundamentals of Federal Taxation. Contributor to legal periodicals. With firm of Poletti, Diamond, Roosevelt, Freidin and Mackay, New York City. 
ums to maintain the funds with which to pay claims, to meet the cost of business expenses, and to yield profits. ${ }^{1}$ Premiums are presumably based upon the risk undertaken at the outset.

Insurers rely upon their contracts to define the insured events, the excepted causes, and to lay down conditions of coverage. An "insured event" is an event, the happening of which is the contingency giving rise to the promise to pay; for instance, under a life insurance contract the death of the insured party is the insured event. An "excepted cause" is a clause which relieves the insurer from liability if the insured event results from that particular cause. A typical excepted cause is death by suicide under a life insurance contract.

The insurer further delimits the risk he assumes by incorporating conditions in his policy which are significant to the hazard, and the compliance with which by the insured diminishes the possibility of loss as viewed at the outset of the transaction. An example would be a clause in a fire insurance policy declaring the policy invalid if the insured keeps gasoline on his premises. These are properly conditions precedent, ${ }^{2}$ though in insurance usage such conditions are termed "warranties." Further discussion of "warranties" in insurance policies will be developed below.

In addition to his ability to select and control risks through the contract ${ }^{3}$ as written, ${ }^{4}$ the insurer may utilize certain interrogations of insurance applicants to ascertain whether he will undertake the risk requested. These ordinarily yield statements by the insured, made presumably to induce the insurer to act and generally known as "representations." Representations, then, fit into the selection and control of the risk pattern in that they are illuminative of the facts surrounding the risk, and go to influencing the insurer's judgment.

If a representation were to be the heads on a coin, concealment would be the tails. While representation is the communicated affirmation or denial of a proposition of fact material to the risk, concealment is, in insurance law, the failure of the insured to disclose to the insurer, without being asked, known facts which the insurer would regard as material to the risk. The concealment doctrine aids the insurer in select-

\footnotetext{
1 This discussion does not take into account the compulsory insurance laws of various states, such as the Massachusetts compulsory automobile liability insurance law and the many workmen's compensition programs. Social purposes of government may make certain forms of insurance coverage so desirable as to have its administration conducted at a loss because of the prohibitive premiums which would otherwise be dictated by the nature of the risks involved.

"Restatement, Contracts \$250 (1932). For a detailed analysis of "conditions" in insurance contracts, sec Harnett and Thornton, The Insurance Condition Subsequent: A Needle in a Semantic Haystack, I7 Ford. L. REv. 220 (1948).

${ }^{3}$ It must be remembered that insurers are not typically allowed full freedom of contractual provision. Most jurisdictions, in the exercise of regulatory powers, establish certain mandatory policy provisions, such as the New York Standard Fire Insurance Policy, N. Y. Ins. Law \$168; or exclude certain types of provisions, for instance, N. Y. Ins. Law $\$ \mathrm{I}_{43}(2)$; and grant broad, discretionary powers to the State Insurance Superintendent or Commissioner in regulating the contents of insurance policies. N. X. INs. LAw $\$ 169$.

- A common protection for fire and automobile liability insurers is the insertion of cancellation clauses, enabling the insurer to terminate the contract without cause upon notice to the insured. E.g., lines $56-67$ of New York Standard Fire Insurance Policy ( 1943 form). Life, accident and health, surety, and marine contracts of insurance typically do not have such clauses.
} 
ing and controlling his risks by allowing the insurer to presume that nothing material is being kept from him. As a power factor, the ability of the insurer to avoid liability on a policy issued under circumstances of concealment is a deterrent to those who would otherwise be tempted to conceal. The doctrine has further relevance to risk selection in that the concealment leads to the ultimate contention that the risk actually assumed was not the same risk contemplated by the insurer when he entered into the contract.

There are many miscellaneous methods by which risks may be controlled, and while they are significant in the business usages, their exposition is purposeless to this article. Constant inspection, periodic reports, education, and customer servicing are such instances of control of hazard.

\section{B. A Close Focus on Concealment}

Concealment, in private insurance law, is essentially a non-disclosure. This is a departure from the customary meaning of the term in the law of contracts generally, where concealment connotes an affirmative act to hide the existence of a material factor. ${ }^{5}$

In the law of contracts, there is no general duty upon one contracting party to come forward to disclose facts that the other party would deem material in determining whether to enter the contract, but such duty does exist in special situations. ${ }^{6}$ A well known example is the duty of a fiduciary so to disclose when contracting with his beneficiary. In the schema of contract law, then, the doctrine of concealment presents a special exception to the rule that a contracting party has no general duty of disclosing facts. It must be remembered, however, that even in the wide field of contracts a party may not remain safely silent under all circumstances; the possibilities of rescission because of unilateral mistake and the application of rules pertaining to fraudulent inducement of action are interplaying factors which will be the subject of extended discussion below.

The Latin maxim uberrimae fidei reverberates joyfully through this section of the law. The unsmiling jurist says insurance contracts are uberrimae fidei when he means to say that they involve the utmost good faith. While such terminology advances few but the purveyors of legal dictionaries, it is significant to note that concealment is a doctrine applicable to the insured, it is concealment by the insured. The omissions of insurers must be remedied under some other legal facets. The doctrine of concealment, then, as the principal mirror flashing uberrimae fidei through the insurance tomes, is actually little concerned with anyone's good faith but the insured's.

In modern insurance practice, ${ }^{\top}$ the problem of concealment arises as a practical

- Restatement, Contracts $\$ 472$ (1932). Also see Restatement, Restitution $\$ 8$, comment $b$ (1937): "Concealment is any statement or other conduct which prevents another from acquiring knowledge of a fact, such as diverting the attention of a buyer from a defect which otherwise he would have observed."

- See Restatedent, Restitution $\$ 8$, comment $b$ (1937).

The author cautions the reader that there is much variation in insurance practice and business 
litigious matter in two principal situations. One is that involving the insurance policies which are written without the submission of a formal written application. These are generally inland marine, ${ }^{8}$ liability, fidelity, casualty, and fire risks. As a business usage, much of this insurance is obtained by telephone calls from brokers or insurance consumers directly, and the insurer is interested only in several general questions which are calculated to define the risk. Items such as location, worth, and description of the subject insured typically suffice. The failure of the insurer to elicit a variety of specific questions, in many cases, leads to the eventual assertion, after the occurrence of a loss, that the insured should have come forward and advised the insurer of the existence or nonexistence of a factual condition which the insurer would have regarded as important. This area of concealment, however, quantitatively viewed, is of smaller significance than that of another field.

The bulk of concealment cases involve the so-called interim period between the execution by the insured of an application for a life insurance policy and the delivery of the policy, a period which normally varies from one week to one month. Life insurers customarily require the applicant to fill out a written application form containing an extensive questionnaire of facts deemed relevant to the risk by the insurer. In the interim period, however, following the submission of the application, but prior to the delivery of the policy, the insured may become aware of additional or changed facts which are material and which render statements in the application untrue.

These two situations invoke the doctrine of concealment. The legal significance of a successful assertion of concealment by the insured is rooted in defense, the insurer having the ability to avoid the policy or to sue for rescission. It does not appear in the reported cases that an insurer has ever launched a suit for damages based upon concealment.

\section{Warranty, Representation, and Concealment Distinguished}

It is necessary in adjusting to the correct perspective to define precisely the terms "warranty," "representation," and "concealment." A warranty, generally speaking, is a term of an insurance contract "which has the effect of requiring, as a condition precedent of the taking effect of such contract or as a condition precedent of the insurer's liability thereunder, the existence of a fact which tends to diminish, or the non-existence of a fact which tends to increase, the risk of the occurrence of any loss, damage, or injury within the coverage of the contract." ${ }^{\text {" }}$ The warranty as it is used in insurance law must not be confused with the promissory character of the warranty in the law of sales. In insurance, the breach of the warranty by the insured is not

techniques. All general statements made herein are subject to local exception. Some lack of precision is the compromise in the conflict between policy analysis and brevity.

8 "Inland marine" as a phrase is part carry-over of terminology and part pun. It covers generally that group of policies known as "floaters," which are of an all risk type, and not limited to fixed locaions. Marine insurance companies are usually empowered to write this coverage.

N. Y. Ins. Law $\$ 150$. 
actionable by the insurer; it can only operate by way of condition. Actually, a warranty may be a statement by the insured which is inserted in the contract or may be a condition inserted by the insurer.

A representation is a "statement as to past or present fact made to the insurer by ... the applicant ... at or before the making of the insurance contract as an inducement to the making thereof."10 The representation is a statement extrinsic to the contract which induces the insurer to contract. Observe that a statement by the insured which is written into the policy is a warranty because of its express inclusion as a contractual condition.

In the field of life insurance, this common law distinction between representation and warranty has been infringed upon by statute. Most states have statutes which provide that the insurance policy and all applications physically annexed thereto constitute the entire contract between the insurer and the insured. The purpose of this is to eliminate incorporation by reference by the insurer of obscure conditions in by-laws, printed rules, and similar documents. The attaching of the application to the policy, therefore, means that all statements made by the insured in the application become part of the policy, i.e., the entire contract. Consequently, under strict common law rules, these statements would be warranties. However, these statutes typically include the further provision which expressly provides that all statements made by the insured in life insurance applications are to be deemed representations and not warranties. ${ }^{11}$

The reader must not believe that every statement in a life insurance application that is a representation is a bold declarative utterance on the part of the insured. Very often the statement is made in the form of an answer to a printed question, and this answer may be "yes" or "no," or perhaps a check-mark in an appropriate position. ${ }^{12}$ A nudge of the pencil may constitute a representation.

The law of misrepresentation is very complex and extremely significant in the field of private insurance. ${ }^{13}$ There is no place in this article for a fair presentation of this important topic. It will suffice at this point to state that there are two general rules used in this country in determining the character of misrepresentations that will avoid a policy of insurance. It is probable that in the absence of statute the weight of authority is in accord with the holding that an innocent material misrepresentation of a past or present fact will entitle the insurance company to avoid the policy. ${ }^{14}$ Some states adopt this rule by statute. ${ }^{15}$ The opposite view, probably entertained by a majority of American jurisdictions, is that it is not enough for the insured to misstate a material fact, the further requirement being imposed that the insured make the misrepresentation with the knowledge of its falsity. ${ }^{10}$

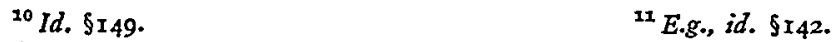

${ }^{13}$ Sec Becker v. Kansas Casualty \& Surety Co., ro5 Kan. 99, r8r Pac. 549 (19r9).

${ }^{13}$ For a complete study of this subject, see Harnett, Misrepresentation in Life Insurance Applications: An Analysis of the Kansas Law and a Proposal for Reform, 17 J. Bar. Ass's Kansas 214 (1948).

14 Wirliam R. Vanice, Handbook of the Law of Insurance 365 (2d ed. r930).

${ }^{20}$ E.g., N. Y. INs. LAW §r 49 .

${ }^{20}$ E.g., Metropolitan Ins. Co. v. Burno, 309 Mass. 7, 33 N. E. 2d 5 r9 (194r). 
A representation is an affirmative action on the part of the insured; concealment is a nondisclosure. In a sense, it may be said that a concealment is a constructive misrepresentation by silence, that the insured in procuring a policy of insurance says, in effect, "I have told you all the material facts that I know." The overlap between misrepresentation and concealment will be the subject of discussion below, but here the point must be noted that concealment is a different thing than misrepresentation. It is the difference between misstatement and silence.

\section{Materiality of Facts}

Whether the discussion is of concealment or of representation, the key point is the materiality of the fact. It is necessary that a fact be material before the drastic legal consequences flowing from misrepresentations and concealments be unleashed.

Materiality has as its reference point the bearing on the acceptance of the risk. Consistent with the principle that the insurer must be able to select and control the risks undertaken, a fact occupies that status known as materiality when the insurer's knowledge of the facts would result in his refusal to enter that particular contract of insurance. Therefore, materiality deals with those facts which influence the insurer in writing that particular contract-the facts which influence him at the outset.

The tests vary in different jurisdictions. The probable common law test is: if he had knowledge of the true facts would a reasonably prudent insurer have made this contract.17 Other jurisdictions use the test of what might this insurer have done. ${ }^{18}$ The third test is the New York statutory ${ }^{19}$ formulation-with knowledge of the true facts, would this insurer have made this contract.

It perhaps goes without saying that the insurance company must have relied upon the nonexistence of the fact concealed, and if the insurer either knew the actual fact or was chargeable with the knowledge of this fact, it could not be said that the insurer relied upon the insured's silence.

\section{III}

\section{The Traditional Rationales Analyzed}

\section{A. "Three" Justifications}

The doctrine of concealment is the embodiment of the insurer's ability to avoid liability on a policy of insurance on the ground that the insured failed to disclose a fact material to the risk, and the rules by which the doctrine finds effect will be examined. It has been pointed out that the imposition of a general duty of disclosure is an exception to the normal patterns of contracts law. But, before immersing the discussion in the substantive aspects of the insurance law of concealment, it would be helpful to post clearly in mind the traditional rationales advanced to justify the adoption of this special duty to disclose. These may be divided into three

\footnotetext{
${ }^{22}$ Fidelity \& Casualty Co. of New York v. Middlemiss, y03 Utah 429, I35 P. 2d 275 (1943).

${ }^{18}$ See Note, II5 A. L. R. 93 (1938). ${ }^{20}$ N. Y. INs. LAw 5149 (1939).
} 
rough categories: (I) The absence of concealment is an implied condition of contracts of insurance. (2) Concealment prevents a meeting of the minds. (3) The duty arises because of a special relationship of trust and confidence in that the insurer depends upon the insured's superior knowledge of the facts in calculating the risk..$^{20}$

The first so-called justification is merely a verbal circle. To say that the absence of concealment is an implied condition ${ }^{21}$ is not to answer the question but only to rephrase it in a declarative style. The true inquiry is why should a duty to disclose be established; what is the reason for the erection of an implied condition? This position has not even a colorable claim to be termed a justification.

Considering that the subject matter of this article is limited, the author feels obliged to constrain his feelings in discussing the "meeting of the minds" notion. The feeble old bromide that a contract cannot be valid unless there is a meeting of the minds of the contracting parties continues to receive lip service in the law of insurance contracts, ${ }^{22}$ just as it does throughout contracts generally. This is subject to criticism in two respects. First, "meeting of the minds" is too extreme a statement of the contractual requirement of mutual manifestation of assent, ${ }^{23}$ many contracts being enforceable even though the parties' minds "did not meet" in a true consensus. Secondly, this position also avoids the true question. The requirement of "meeting of the minds" is recognized by its enthusiasts as a prerequisite to all contracts, yet the extraordinary requirement of disclosure applies only to certain contracts.

The third position is the defensible rationale. It was first set forth in the notable quotation from Carter v. Boehm: ${ }^{24}$

Insurance is a contract upon speculation. The special facts, upon which the contingent chance is to be computed, lie most commonly in the knowledge of the insured only: the underwriter trusts to his representation, and proceeds upon confidence that he does not keep back any circumstances in his knowledge, to mislead the underwriter into a belief that the circumstance does not exist, and to induce him to estimate the risque, as if it did not exist. The keeping back [of] such circumstances is a fraud, and therefore the policy is void. Although the suppression should happen through mistake, without any fraudulent intention; yet still the underwriter is deceived, and the policy is void; because the risque run is really different from the risque understood and intended to be run, at the time of the agreement.

This sets up the insurer-insured relationship as involving a confidence, and the apparent assimilation to fiduciary concepts leads to a duty of disclosure. It makes clear that the insurer is known to gauge his risk-assuming conduct on the facts given to him, and has the right to believe that all material facts have been told to him. In

${ }^{30}$ These are pointed out in Edwin W. Patterson, Cases and Materials on Insurance 586-587 (2d ed. 1947 ).

${ }^{21}$ Kohne v. Insurance Co. of North America, 14 Fed. Cas. 835, No. 7920 (C. C. D. Pa. 1804); Blackburn, Low \& Co. v. Vigors, 17 Q. B. D. 553 (1886).

22 George Richards, The Law of Insurance 122 (4th cd., Rowland, 1932).

${ }^{23}$ Restatement, Contracts, Topic 2 (I932).

94 3 Burr. 1905, 1909, 97 Eng. Rep. I162, I164 (K. B. 1776). 
a sense this position is also incomplete, because it may be asked why a relationship of confidence should be established in this type of contract and not in others.

To say that insurers must be protected in their undertakings is to restate the question; to say that insurance is a vitally important socio-economic function and that therefore the continuance in business of the contracting parties known as insurers must be underwritten by the courts through the application of extraordinary contract rules, is to state a value judgment of no small proportions.

True appraisal of the doctrine, and its rationale, must be preceded by an understanding of its historical background. The estimate of the extent to which the concept is a petrification of history, and the amount of social utility it presently retains, is the task of this essay.

\section{B. The Historical Ingredient}

The landmark case in the origin and development of the doctrine of concealment is the famous old case of Carter $v$. Boehm. There an English fort located in Sumatra was insured against enemy capture. It appeared that there were several notable weaknesses in the fortifications, and when a loss occurred through enemy capture, the insurer denied liability claiming that the person taking out the insurance did not disclose several letters which revealed the fort's susceptibility to capture. The decision was in favor of the insured, but in dictum, Lord Mansfield laid down the classic rule that innocent concealment by the insured of a material fact makes the insurance contract voidable. He said, in part: ${ }^{26}$

The special facts, upon which the contingent chance is to be computed lie most commonly in the knowledge of the insured only. . . .

At the early date of this case, the commercial insurance business was in its infancy in England, and consistent with the maritime economy of the Island, marine insurance was the developmental forerunner.

Marine insurance was written, then, with the "lost or not lost" provision, which meant that the insurance was applicable even if at the time the policy took effect the ship was already lost at sea. This situation could arise because it was a usual practice to insure vessels after they had sailed. Because of this, and because of the insurer's inability to inspect the vessel in many cases, the contract was pretty much of a blind leap for the insurer. It has been ably commented $:^{27}$

The imposition of a duty to disclose was justified by the way in which marine insurance was then written. The ship was frequently at a distance when the policy was written; it was quite common for the insured not to procure insurance until the voyage had begun. The instruments of communication were slow and unreliable. Lloyd's List and similar sources of information were yet to be established. No inspection of the ship was possible, and the insured knew far more about it than did the underwriter. The insured was a

${ }^{25}$ Id. at 1905,97 Eng. Rep. 1162.

20 Id. at rg09, 97 Eng. Rep. Ir64.

${ }^{27}$ Edwn W. Patterson, Essentials of Instrance Law 38x (x935). 
merchant or ship owner who could interpret the significance of facts that he knew, as well as could the underwriter. It should be noted further that the marine policy contained very few warranties and that the only written application made by the insured was a brief statement describing the risk, such as is in use at Lloyd's today. The growth of Lloyd's was an important factor in the development of British shipping and overseas trade. A rule of law that lightened the underwriter's burdens contributed to this growth.

The doctrine of concealment was actually unfolded in the English common law of marine insurance in the latter half of the eighteenth century. A concentrated effort was made to nurture and to encourage the new insurance industry. The circumstances of underwriting were such that the marine insured demanded and received insurance of an extremely hazardous variety. $\mathrm{He}$ was the expert in the marine field; the underwriters entertained no superior technical knowledge. The great probabilities were that if a fact was material, and if the shipowner knew the fact, the shipowner would know the fact was material. Because of the great risk assumed, with the insurer operating on a minimum of information, the social policy of fostering the continuance of marine insurance forged the requirement of disclosure by the insured of the material facts he knew.

IV

\section{The Substantive Law of Concealment}

The effect of the doctrine of concealment has been to create rather notorious confusion in the case law of insurance. ${ }^{28}$ It would be indeed a cumbersome task with little effective result to treat exhaustively the multitude of cases in this area and so no such effort is made.

\section{A. The Variables}

The key to understanding concealment is contained in a combination of specific variables. These are as follows: ( 1 ) The insured knew the fact; (2) The insured did not disclose the fact to the insurer, and the insurer was not chargeable with its knowledge; (3) The fact was material; (4) The insured knew the fact was material.

Combinations of these elements form the currently prevailing rules on concealment. The relationship between the fourth variable and intent to deceive will be discussed below.

\section{B. The English Law}

The English law is of concern because of the historical antecedents, as well as the prominent effect registered by British insurers on American business.

England follows the flat rule laid down by Lord Mansfield: innocent concealment of a material fact avoids the policy. The English rule, then, contains only three variables: ( $\mathrm{r}$ ) The insured knew the fact; (2) The insured did not disclose the fact to the insurer, and the insurer was not chargeable with its knowledge; (3) The fact was material.

\footnotetext{
${ }^{28}$ VANCE, op. cit. supra note I4, at 339-354.
} 
There is no requirement of the fourth variable, namely, that the insured knew that the fact was material. Innocent concealment means the failure of the insured to disclose a fact the existence or nonexistence of which he knew, but the materiality of which he was unaware.

This is a tough rule, and it is applied by the English to all insurance contracts. ${ }^{29}$ In England, a policy is avoided if the insured knows a fact, does not disclose it, and if the fact is material. There being no requirement of fraud or bad faith, innocent concealment lets out the insurer.

\section{The American Law}

I. Differences According to Kind of Insurance

\section{a. Marine Insurance}

In marine insurance, the strict English rule carries over. Consequently, in this country the English rule is known as the "marine rule."

Therefore, the marine rule may be stated as follows: (I) The insured knew the fact; (2) The insured did not disclose the fact to the insurer, and the insurer was not chargeable with its knowledge; (3) The fact was material.

As said early by the United States Supreme Court in a noted marine insurance case, ${ }^{30}$

The duty of communication, indeed, is independent of the intention, and is violated by the fact of concealment even where there is no design to deceive.

b. Non-marine insurance

\section{(I) The Fourth Requirement}

The strict English rule has the curious effect of making the insured an insurer as to the non-materiality of all known facts not disclosed. An insured might not have the slightest idea that a particular fact is material, yet this unawareness does not matter.

The feeling developed early that such a rule worked hardship in many cases. While the situation of the insurer and the crafty shipowner testily sipping coffee in the early days of Lloyds may have presented a suitable subject for the operation of the rule, there were many situations to develop in which such suitability was absent.

The fundamental policy behind the English rule was that the insurer required protection on two grounds. First, the inaccessibility of the subject insured deprived the insurer of the opportunity to inspect and investigate the risk; and second, the insured possessed an expertness at least the equal of the insurer in all matters pertaining to the risk.

\footnotetext{
${ }^{28}$ The case of Horne v. Poland, [1922] 2 K. B. 364,127 L. T. R. 242 , has been taken as indicating a wavering of the British position. There, a Rumanian moved to England at the age of 12, settled in England, and Anglicized his name. When he was an adult he procured a burglary policy without disclosing that he was an alien. When the insurer proved that the fact that the insured was an alien was material to the risk, the court found for the insurer. However, the court intimated that their decision is based on the fact that the insured as a reasonable man ought to have known his alien status was material.

${ }^{\text {so }}$ Sun Mutual Insurance Co. v. Ocean Insurance Co., 107 U. S. 485,510 (1882).
} 
With the growth of the great insurance industry, life insurance and fire insurance emerged as commanding features. The reasons for the English rule, also known as the marine rule, were not only less cogent in the case of life and fire insurance, but were largely inapplicable. Life insurance underwriting is a technical business, requiring skill. Even within the business there are degrees of technology: consider the actuaries who are the despair of their non-arithmetic colleagues of the law. Fire insurance underwriting is involved, risk evaluation in many cases being far beyond the insurance buyer's training. The expertness is in reality concentrated in the insurer in life and fire lines, with occasional buyer expertness being fortuitous. And the insurer has almost unlimited accessibility to the subject matter of the insurance, fire insurance being a relatively fixed location coverage, and life insurers demanding complete physical examinations.

As a result, the feeling grew that something more than the three elements of the English rule should be present. In the well known case of Penn Mutual Life Insurance Co. v. Mechanics' Savings Bank \& Trust Co., ${ }^{31}$ Circuit Judge William H. Taft stated: $:^{32}$

It is clearly just to require that nothing but a fraudulent nondisclosure shall avoid the policy. Nor does this rule result in practical hardship to the insurer, for in every case where the undisclosed fact is palpably material to the risk the mere nondisclosure is itself strong evidence of a fraudulent intent. Thus, if a man, about to fight a duel, should obtain life insurance without disclosing his intention, it would seem that no argument or additional evidence would be needed to show the fraudulent character of the nondisclosure.

In this case, a bank clerk procured life insurance while he was systematically embezzling bank funds. He did not disclose this activity to the insurer, but after the policy was issued he was caught, and subsequently died from a brain congestion brought on by the accumulated mental stress of the embezzlements and detection. The court assumed the embezzlements to be material; there were other questions in the case, but it was indicated that concealment was not a valid defense where the insured did not know the fact was material.

This case has been cited widely, and its principles have gained broad acceptance in the life insurance field. However, several courts continue to cling to the marine rule in non-marine insurance, ${ }^{33}$ although this is not the majority view. ${ }^{34}$ Concealment is not generally a statutory subject, but several states adopt the strict marine rule throughout by virtue of express statutory provisions. ${ }^{35}$ Occasionally, language crops out to the effect that only the facts which a reasonable man ought to know

3272 Fed. 413 (6th Cir. 1896 ).

12 Id. at 435 .

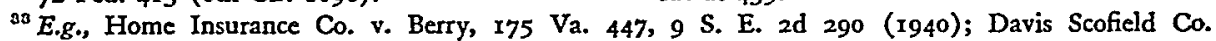
v. Agricultural Insurance Co., 109 Conn. 673, 145 Atl. 38 (1929).

34 See collection of cases in VANCE, op. cit. supre note 14 , at $343 \mathrm{n}$.14. It is worthwhile to note that lines I-3 of the New York Standard Fire Insurance Form (r943) state that the policy "shall be void, if whether, before or after a loss, the insured has wilfully concealed or misrepresented any material fact. ..."

${ }^{38}$ See the statutes construed in New York Life Ins. Co. v. Fleck, 73 N. D. 143, I2 N. W. $2 d$ 530 (1944); Gates v. General Casualty Co. of America, 120 F. 2d 924 (9th Cir. 194x). 
would be material must be disclosed. ${ }^{36}$ Although modern technology and communications have torn down the reasons for the rule even in the maritime field, the strict marine rule (the English rule) is retained uniformly in the field of marine insurance.

The non-marine rule contains the three elements of the marine rule, and one more. It requires the insured's knowledge of the fact and nondisclosure of the fact to the insurer who is not chargeable with its knowledge and materiality. But in addition, the nondisclosure must have been in bad faith. The meaning of this last requirement is muddy in the very best tradition of empty legal verbalisms. Some courts tell us the disclosure must be fraudulent, ${ }^{37}$ others say there must be an actual intent to deceive. ${ }^{38}$ Then others rush in to say that a reasonable man would have known the fact was material, and that therefore the insurer's defense of concealment is effective. ${ }^{39}$ Presumably, if an insured ought to have known, but did not actually know, then his conduct is not fraudulent, nor is there intent to deceive; yet the requirement of "ought to know" is not to be found in the strict marine rule.

The logical and the only predictable analysis lies in the separation of requirement and proof. The social pulls dictate that as a minimum, the insured have some fault clinging to his conduct. The fault, in the ultimate analysis, is that the insured remained silent with the knowledge that the insurer would not have accepted the risk had the fact been disclosed, i.e., that the insured knew the fact was material. ${ }^{40}$ This silence is rooted in the hope that the insurer will issue the requested policy, which policy would not have been forthcoming in the presence of disclosure. This is the so-called intent to deceive. The inducement of action through nondisclosure is the ostensible fraud.

But, it must be proved that the insured knew the fact was material. The insured's knowledge is a subjective thing, requiring the insured's own admission for the most likely proof. Surrounding facts and circumstances, in an objective approach, however, may be used to prove the existence of a subjective status-the insured's state of mind. The insured's conduct and common knowledge may lead to the inference that the insured must have known the fact was material, notwithstanding his vigorous denial. Since insureds typically deny knowledge of materiality, objective evidence is always invoked to prove a subjective thing-the state of mind of the insured. This is what courts grope for when they say that a reasonable man ought to have known the fact was material. The situation is better stated in Judge Taft's dueling analogy in the Penn Mutual case, wherein he pointed out that the procurement of a life insurance policy on the way to fight a duel was "fraudulent" because the fact was "palpably material." Palpable materiality is really an especially obvious set of

${ }^{\text {so }}$ See Hartford Fire Ins. Co. v. Golden, I88 Ky. 742, 224 S. W. 177 (1920); Pelzer Manufacturing Co. v. American Fire Ins. Co., 36 S. C. 213 , I5 S. E. 562 (189x).

37 Penn Mutual Life Ins. Co. v. Mechanics' Savings Bank \& Trust Co., 72 Fed. I43 (6th Cir. 1896 ).

${ }^{s 8}$ See Romain v. Twin City Fire Insurance Co., 193 Minn. I, 258 N. W. 289 (1934).

${ }^{39}$ See note 36 supro.

${ }^{\text {to }}$ See discussion of materiality at page 396 , supra. 
facts, where a person could not help but know that the insurer would not accept the risk if the fact was disclosed.

There may be disagreement as to the inferences to be drawn from a factual situation. For instance, in one case ${ }^{41}$ the insured did not disclose that he had accused someone of committing adultery with his wife, and he did not disclose that he carried a revolver, for fear of being killed by the man he had accused. The insured was shortly thereafter killed in an unsolved crime. The court upheld a directed verdict for the beneficiary, stating there was no jury case for a concealment defense. It may be argued that this case presents an analogy to the dueling case. Palpable materiality invokes an evaluation of the probative force of a set of facts as to whether that insured really believed facts to be material. Since knowledge is subjective, palpability should be brought down to the specific insured.

The non-marine rule, in summary, has four prerequisites: ( 1 ) The insured knew the fact; (2) The insured did not disclose the fact to the insurer, and the insurer was not chargeable with its knowledge; (3) The fact was material; (4) The insured knew the fact was material.

\section{(2) Inland Marine Insurance}

The rapidly expanding area of inland marine insurance has presented an interesting challenge to the doctrine of concealment. Inland marine insurance developed out of the demand for adequate coverage of portable personal property. The marine insurers were the logical ones to initiate this type of writing, in so far as they were already experienced in the risks attendant on water travel, and the floaters actually represented an extension to inland travel. ${ }^{42}$

In New York, for instance, personal property floaters are within the statutory definition of "marine insurance," though in popular parlance they are known as inland marine. This leads to the problem in a concealment case as to whether the courts should apply the marine rule or the non-marine rule in inland marine insurance cases.

There have been two very significant cases in this area in the last eight years. The first was Blair v. National Security Insurance Co. ${ }^{44}$ In that case the plaintiff procured a jewelry-fur floater policy without disclosing that she had suffered many prior losses and was then in financial difficulties. A loss later occurred under very suspicious circumstances. Although there was a case of palpable materiality, the issue was framed solely on the correctness of the insurer's request to charge the jury that the marine rule was applicable. The court found for the plaintiff, stating that the nonmarine rule was the correct one to apply in the case of inland marine insurance.

In Stecker v. American Home Fire Assur. Co., ${ }^{45}$ the insured was a salesman who procured a "salesmen's fur floater" policy, which covered him for loss or damage to

\footnotetext{
${ }^{41}$ New York Life Insurance Co. v. Bacalis, 94 F. 2d 200 (5th Cir. 1938).

"2 See Blair v. National Security Co., I26 F. 2d 955 (3d Cir. 1942).

${ }^{48} \mathrm{~N}$. Y. INS. LAW $\$ 46(20)$.

6 299 N. Y. I, 84 N. E. $2 d 797$ (1949). 
his furs while they were being transported around the country for sale to his customers, without disclosing to the insurer that six years previously he had been convicted in a federal court of the crime of concealing assets from his trustee in bankruptcy. The insurer sought no information from the insured on this subject. After the loss occurred, the insurer contended that the marine rule applied and the nondisclosure discharged him. The court held for the insured, citing the Blair case, and applied the non-marine or, as it is sometimes called, the "ordinary rule."

The court said, in part: ${ }^{46}$

Until the legislature says otherwise, we hold that the "ordinary" rule, as to nondisclosure, is the one to apply in respect to policies like the one in suit, and that as, to such policies, if the insurer makes no inquiry, and the insured no representation, as to the fact in question, then concealment, short of actual fraud, in respect to such a fact, does not void the policy.

These cases show the courts caught between the label of the insurance and the reason for the rule. In holding that the marine rule applies only to wet risks, and that the non-marine rule is applicable to dry inland marine risks, both courts make it plain that the reason for the rule governs. The twin factors of accessibility of the risk, with consequent ease of inspection, and the superior expertness of the insurer are decisive.

\section{(3) Interim Nondisclosure in Life Insurance}

Applicants for life insurance execute detailed written applications in which certain representations are made. The policies issued in response, however, are generally issued several weeks later. A problem in concealment arises when facts are discovered during the interim period which make statements in the application untrue.

The United States Supreme Court ${ }^{47}$ has summoned trusted old uberrimae fidei to show that the insured must disclose material facts learned in the interim period. But it is well settled in life insurance law that interim nondisclosure must be in "bad faith" in order for the insurer to successfully defend on account of concealment. Hence this is the non-marine rule. ${ }^{48}$

\section{Some Comments on Disclosure}

The closing of the contract of insurance terminates the duty of disclosure. ${ }^{40}$ This is subject to modification by express contractual terms.

In the time preceding the making of the contract, the general rule is that the insured is under no duty to investigate the circumstances of the risk. Concealment. involves actual knowledge of the circumstances. ${ }^{50}$ The rule is doubtful where the insured is suspicious, but it probably is that concealment will be invoked only if the grounds for suspicion themselves should be disclosed.

\footnotetext{
"Id. at 8,84 N. E. $2 \mathrm{~d}$ at 800 . (Italics supplied.)

${ }^{47}$ Stipcich v. Metropolitan Life Ins. Co., 277 U. S. 311 (xg28).

${ }^{18}$ Wilkins v. Travelers Ins. Co., Ir7 F. 2d 646 (5th Cir. 194r).

40 Springfield Fire \& Marine Ins. Co. v. National Fire Ins. Co., 51 F. 2d 7r4 (8th Cir. 193r).

${ }^{50}$ American Employer's Ins. Co. v. Cable, ro8 F. 2d 225 (5th Cir. 1939).
} 
A point which escapes many is that the "insurance broker" is the agent of the insured," while the "insurance agent" is the agent of the insurer. Consequently, a disclosure by the insured to his own broker is not a disclosure to the insurer, and a concealment by the broker is a concealment by the insured. ${ }^{\mathbf{2} 2}$ This should be a warning for insurance buyers to select trustworthy brokers, for the broker can bring down the consequences of concealment upon the insured even though the insured himself was completely honest. Note, however, that a disclosure to a broker may not be a completely useless thing, for it may be taken as an indicia of good faith..$^{\text {b3 }}$

Generally, ${ }^{54}$ the nondisclosure by an agent of the insured, for example, an officer of a corporate insured, is imputed to the principal if the disclosure would be in the course of the officer's authority. ${ }^{55}$

The insured need not disclose facts of general knowledge, ${ }^{56}$ or facts which are known to the insurer. ${ }^{57}$ The nub of concealment is the deceiving of the insurer, and if the insurer was chargeable with knowledge of the fact not disclosed he could not be said to have been deceived. The insurer is under no duty to make an investigation, although he may be where suspicious facts are revealed, ${ }^{58}$ provided the grounds are definite. ${ }^{59}$ When the insurer does investigate, he does not rely upon the insured. ${ }^{60}$

It is occasionally stated that the insured need not disclose self-disgracing or embarrassing facts, ${ }^{61}$ but this is unreliable privilege at best. In many cases disclosure of facts which were deprecating has been required where they were material. ${ }^{62}$

\section{V}

\section{Friction Points Between Concealment and Misrepresentation}

The relationship of the doctrine of concealment to misrepresentation is such that boundaries tend to become vague. The two principal troublesome spots are the cases of partial disclosure and of interim nondisclosure, particularly in life insurance.

\section{A. Partial Disclosure}

The potential of the partial disclosure situation may be recognized in the facts of Gates v. General Casualty Co. of America. ${ }^{63}$ There the insurer, prior to issuing a

${ }^{52}$ Except that in some jurisdictions the broker is the agent of the insurer for the collection of the first premium.

${ }^{22}$ Hamblet v. City Ins. Co., 36 Fed. Ix8 (W. D. Pa. I888).

${ }^{53}$ See Stecker v. American Home Fire Assur. Co., 299 N. Y. I, 5, 84 N. E. 2d 797, 798 (1949).

64 This article does not purport to treat fully the complex insurance agency problems except to lay the foundation for subsequent discussion.

${ }^{80}$ Davis Scofield Co. v. Agricultural Ins. Co., rog Conn. 673, I45 Atl. 38 (I929).

to Planché v. Fletcher, I Doug. 251, 99 Eng. Riep. I64 (K. B. 1779).

${ }^{67}$ See Alsop v. Commercial Ins. Co., I Fed. Cas. 564 , No. 262 (C.C.D. Mass. I833).

${ }^{58}$ Columbian Nat. Life Ins. Co. of Boston, Mass. v. Rodgers, II6 F. 2d 705 (10th Cir. I940), cert. denied, $3_{13}$ U. S. 56x (I94I); Dossett v. Franklin Life Ins. Co., 276 S. W. I097 (Tex. Com. App. 1925).

${ }^{80}$ See Provident Life \& Accident Ins. Co. v. Hawley, I23 F. 2d 479 (4th Cir. I94I); Great Northern

Life Ins. Co. v. Vince, II8 F. 2d 232 (6th Cir. I94I).

${ }^{\circ}$ Dossett v. Franklin Life Ins. Co., supra note 58.

${ }^{02}$ Penn Mutual Life Ins. Co. v. Mechanics' Savings Bank \& Trust Co., supra note 37.

${ }^{02}$ For example, Tutewiler v. Guardian Life Ins. Co. of America, 42 F. 2d 208 (5th Cir. 1930).

${ }^{\text {Os }}$ I20 F. 2d 925 (9th Cir. I94I). 
motor vehicle liability policy, asked the insured as to his motor vehicle accident experience for the three year period of I931, 1932, and 1933. The insured responded that he had had one accident. After the policy was written, and after the loss occurred, the insurer resisted the claim under the policy on the ground that the insured had suffered many accidents in 1932 and 1933. It appeared that the insured had had one accident in 193r, and he claimed that on answering the insurer's question he had I93I only in mind as a result of a misunderstanding. Applying the strict marine rule, the court found for the insurer on the grounds of concealment.

In so far as the case invokes the concealment doctrine, it is incorrect. The statement made was a downright misrepresentation. If the question is asked, What was your accident record for the past three years?, and the answer is "One," the answerer is stating that he had only one accident in this three-year period; his answer of "One" is false in its entirety. This type of "partial disclosure" is not concealment in the insurance law sense at all; it is misrepresentation.

However, suppose the question is, What was your accident record for 1931, 1932, and I933?, and suppose the answer is "193r, one accident." This is distinguishable from the example above, in that here it may be said that the insurer is asking three separate questions, one as to each year, and that the insured answers one question and leaves the other two unanswered. In the other instance the answer covered all three years. In any event, the authority is fairly clear that where the courts construe questions as severable, and where the insured answers one, and leaves others unanswered, the doctrine of concealment is applicable to the insured's silence if known material facts underlie the unanswered questions. ${ }^{64}$

But there is a further notion existing in this area, and that is the waiver of the concealment where the policy is issued despite the existence of an incomplete answer to a severable question. Several cases allow the waiver, ${ }^{65}$ although the prediction of this sort of judicial conduct is uncertain. The evident theory of the waiver is that the insurer by accepting the unanswered question elects to treat the fact as immaterial ${ }^{86}$ or stated otherwise, the insurer feels that he can accept the risk without knowing this answer, materiality having reference only to an inclination to accept risks. This conflicts in some measure with the principle that the insurer is under no general duty of investigation. The likely conclusion is that the courts regard the unanswered question as a red flag which puts the insurer in the rack of chargeable knowledge. Being given reasonable grounds for suspicion, he must reasonably inquire or investigate. The insurer's clamor at loss time must meet a traditionally high judicial decibel standard if it is to drown out its silence at premium taking time.

\section{B. Interim Nondisclosure}

Interim nondisclosure is really another label for an occurrence which is common

- Phoenix Mutual Life Insurance Co. v. Raddin, I20 U. S. I83 (1887).

${ }^{o s}$ Ibid.; Williams v. Metropolitan Life Insurance Co., I39 Va. 34I, I23 S. E. 509 (1924).

${ }^{68}$ Bowles v. Mutual Benefit Health \& Accident Ass'n, 99 F. 2d 44 (4th Cir. 1938). 
throughout contract law. A contracting party makes a representation to induce the other party before the contract is made. If the representer later discovers his representation of fact is no longer true, a change of circumstances having made the representation untrue, and if this is not communicated to the other party, the latter is induced by a misrepresentation at the time of contract closing. A representation of past or present fact is treated as being made as of the time the contract becomes complete. ${ }^{67}$ This is the principle of "continuing representation."

It is important in life insurance because as we have seen above the non-marine rule is applied to interim nondisclosure. However, as to representations there is a substantial split of authority as to whether innocent material misrepresentation suffices to avoid the policy. This presents a problem of competing analyses. In a jurisdiction like New York which applies the rule that innocent material misrepresentation avoids the policy, the doctrine of continuing representation would lead unyieldingly to the result that if at the date of closing a material misrepresentation was outstanding, the policy is avoided without regard to intent. But if the nonmarine rule of concealment is invoked, there must be bad faith-knowledge of the materiality-before the policy will be avoided. It is to be cautioned, however, that where a binding receipt ${ }^{68}$ is issued with the application, interim nondisclosure probably does not apply because then, for this purpose, the contract would be considered in effect as of the application date.

In jurisdictions which require fault in the insured in both representation and concealment, there is no difficulty. But a jurisdiction like New York must choose between continuing representation and concealment in dealing with interim nondisclosure. Apparently the concealment rules will be applied throughout. ${ }^{69}$

While in practice the usual interim nondisclosure involves the truth of a prior representation, it need not be so. A man can be on his way to fight the duel in his interim period. This would present a pure concealment situation, and would not be complicated by continuing representation.

\section{VI}

Policy Analysis of the Principle of Selection and Control of the Risk

The development of the non-marine rule of concealment has demonstrated rather thoroughly the evaporation of the original grounds for the doctrine in at least life insurance and fire insurance. The pillar of the doctrine was the inaccessibility of the risk to the early marine insurers and the superior experience of the insureds of that day, but there has been a radical alteration of both these circumstances in the insurerinsured relationship in all walks of modern insurance. As to non-marine insurance,

\footnotetext{
${ }^{\circ 2}$ See cases collected VANCE, op. cit. supra note 14 , at $38 \mathrm{I}$ n. 30 .

${ }^{\circ B}$ For a discussion of binding receipts, see Havighurst, Life Insurance Binding Receipts, 33 ILL. L. REv. 180 (1938).

${ }^{\circ 0}$ Stipcich v. Metropolitan Life Ins. Co., 277 U. S. 3 II (I928); Armand v. Metropolitan Life Ins. Co., 134 Misc. 357,235 N. Y. Supp. 726 (Sup. Ct. I929); see Goldstein v. New York Life Inś. Co., I76 App. Div. 813, I62 N. Y. Supp. 1088 (Ist Dep't 1917).
} 
certainly, we find that the present-day justification for the rule must be other than the original basis for the unusual requirement of a general duty of disclosure in a private contract.

The basic policy premise in favor of maintaining the doctrine of concealment is that insurance premiums are made commensurate with the risks undertaken, and that the selection and control of risks is therefore essential to the successful operation of insurance enterprise. In as much as the nature of contractual subject matter is significant in adjusting the price term of most contracts, this is actually a statement that this type of contract is a special one, probably on the grounds that the insurance business is vital in modern social and economic equations, and therefore should be given extraordinary protection.

This position becomes doubtful under careful scrutiny. While it is doubtless true that the insurer plays a very significant role in modern society, there is no provable basis for saying that insurance contracts are more important than brokerage contracts, or sales contracts, or any of many industrial and commercial varieties. The answer may be that this is so, and that therefore there should be a duty of disclosure in all contracts with the rule not being restricted to special types. The author takes no real position on this point, in so far as it involves a more over-all study; this essay is a discussion of the doctrine of concealment taken together with the prevailing social precepts which presumably reflect, through judicial decisions, that a general duty of disclosure is undesirable. It might be that the category of contracts receiving special treatment might be broadened. However, this line of inquiry is absorbed in the immediate question-whether the insurance contract itself merits inclusion in any such category.

In recognizing the well-founded principle that premiums must be commensurate with the risk, it must not be forgotten that there are several principles operating in direct competition. Generally speaking, a promisor is under a duty to perform his contractual obligations even though he has made a bad bargain. In addition, the insurer assumes the risks of mistakes which occur in an investigation which he himself launches. If there is a belief that the insurer should know all material facts at the insured's peril, why should it make any difference that the insurer made some effort to discover the facts and failed to do so. Indeed, discouragement of investigation by the insurer removes a factor which could materially improve the insurer's evaluation of the risk. Furthermore, the superior technical knowledge and typical economic affluence enjoyed by the insurer have led courts to look favorably upon insureds as parties-plaintiff, and caused them to be concerned with a fairness to people who are, in the final analysis, stated to be common laymen just wandering about. ${ }^{70}$ The well-advertised slogan that insurance contracts are "contracts of

7o The judicial recognition of insureds as constituting an unclassified herd of lambs must not be confused with the growing reality in the insurance business of organized buyer resistance. Large business concerns, as well as large scale associations. of insurance buyers, are forces to be reckoned with by the insurers, who are themselves really businessmen who need customers to stay in business. 
adhesion" stems from this type of thought, the feeling being that since the insurer can lay down the contractual terms, he can protect himself and is in fact deemed to be protecting himself. This does not take into account the large measure of state regulation of insurance companies, which is very strong in life insurance and fire insurance.

The concept of fairness obtains recognition on both sides of the argument as to the retention of the concealment doctrine. Overly much liberty with the insurance contract may promote cheating by dishonest (which includes the marginally honest) insureds; the temptation to collect money on artificially induced "fortuitous" occurrences is especially strong in the insurance field because of probative handicaps and the lure of ready funds so obviously available. Some insurers are in the habit of admitting that defenses like that of concealment are technical defenses, but state that such defenses are necessary safety valves to prevent the duping of insurance companies.

In short, if the company feels it is being cheated, and cannot otherwise prove the point, it should be able to invoke a technical defense to escape liability. While most insurers are exceedingly trustworthy and would exercise an honest discretion, common principles of fair play demand that an objective third party be the arbiter of disputes. There is no place for the settling of grievances through the unilateral judgment of one party, no matter how benevolent.

\section{VII}

\section{The Proposal: Strike off the Doctrine of Concealment and Substitute Ordinary Contract Rules}

The doctrine of concealment must be stricken from the law of insurance. It was the judicial result of the socio-economic pressures of a time. But the time changed; and pressures flowed into counterpressures, which left a judicial skeleton surviving to meet the challenge of an era in which it has no useful place. It is wrong to neutralize judicial remnants with multifarious exceptions, patchwork relief, and tenuous distinctions. Examination of the two principal areas of the exercise of the concealment doctrine-that where no application is required, and that of interim nondisclosure-shows the true dessert of the phrase "doctrine of concealment" to be rapid consignment to insurance law oblivion.

The insurer comes forward with no good reason why his business should receive favored legal treatment over other similarly vital commercial and social activities. The situation of the insurer and insured has almost reversed since the introduction of the special doctrine, and if either party requires protection in the modern society, it is more usually the insured. This is believed applicable to all branches of insurance, including marine insurance.

Outside of life insurance, with its allied forms of coverage such as accident, health, and disability insurance, and marine insurance, the insurers do not uniformly re- 
quire written applications. In fact, dependent upon local conditions, fire, liability, casualty, fidelity, and inland marine coverages are generally obtainable by telephone, informal letter, or personal conversations. The lack of specific insurer questioning invites the nondisclosure of facts because of the varied traits of inexpertness, ignorance, uncertainty, fading memory, and dishonesty which appear in any representative selection of members of society, let alone a group of insurance applicants.

It is often put squarely to the insurer that if he regards a fact as material, why does he not ask about it. For instance, in the Stecker case, prior to issuing the policy, the insurer could have required the insured to state, either in writing or orally, that he had had a prior criminal conviction. The failure to exercise the ability to ask questions, in which information on material facts could be elicited, is extremely damaging to the insurers who, having taken the premiums in cheerful silence, cry "concealment" when it is time to pay the loss. The Stecker case reflects this sentiment very strongly. ${ }^{71}$

It is contended that the requirement of an application would result in added administrative expense to the insurer and consequently in higher insurance cost to the consumer. If this is assumed to be true, it is still no answer to the failure of the insurer to put forth several basic questions at the point of contact with the insured prior to the writing of the policy. It might be that the small price increases would be compensated for in the additional solidity of the insurance policy obligation. The experience of insurers throughout the industry does not establish the general proposition that application forms themselves mean an expense factor substantial enough to increase the consumer costs, nor that competitive factors would allow this. It goes almost without saying that the more adequate screening of risks would result in the rejection of more undesirable risks, thus increasing the company's fisc through a more favorable loss experience.

The thesis here is not that insurers are to be swindled at will, but merely to subject them to ordinary contract rules as to nondisclosure, and that the defense of "concealment" should be expunged from the insurance law as a special concept.

Where they ask no questions and require no applications prior to the issuance of their policies, insurers should not be heard to complain about nondisclosure of information which could have been simply elicited. This is not to say that the insurer must go out and investigate the circumstances of every risk. No such thing is proposed. Once an insurer receives a representation from the insured, he should be entitled to rely on the representation. ${ }^{72}$ This is not only in accord with accepted

${ }^{72}$ Stecker v. American Home Fire Assur. Co., supra note 53.

72 The extent to which the insurer may rely upon representations is a principal facet of the ever raging controversy as to whether innocent misrepresentation should be grounds for an avoidance of the policy. Those favoring such a rule would allow the insurer to rely completely on the representations. Full discussion of the conflicting views on this subject is beyond the, scope of this article. For an excellent analysis see Prosser, Innocent Misrepresentation of Health in Insurance Applications, 28 Minv. L. Rev. I4I (1944). For the author's views on this subject, see Harnett, Misrepresentation in Life Insurance Applications: An Analyis of the Kansas Law and A Proposal for Reform, 17 J. BAR Ass'N Kansss 214 (1948). 
principles of fair dealing, but is consistent with the common law rule that a contract may be rescinded for material misrepresentation of fact, whether innocent or wilful. ${ }^{73}$ Inadequate investigation would be prejudicial to the insurer, so that the only alternative would be to conduct extensive investigation, and this would raise a cost factor of substantial impact. Then, too, there is a limit to the facts which can be unveiled by the insurer, many of the facts being within the peculiar knowledge of the insured.

The very development of the non-marine rule indicates the futility of the doctrine. If the gist of the doctrine is that the insurer would not have entered into the contract had he known the fact, why is it decisive whether the insured's conduct was wilful? The materiality of the fact is unchanged. Extending this, even the strict marine rule is inadequate, for if materiality of the fact is the sole consideration, the requirement that the insured know the fact is pointless. The explanation is that any root of the doctrine today must be in fairness to the parties.

The law of misrepresentation illustrates interestingly the outmoded nature of the storied uberrimae fidei. As discussed above, several jurisdictions adopt the rule that innocent material misrepresentation avoids the policy; this rule is also known as the "marine rule" of misrepresentation. ${ }^{74}$ But more jurisdictions hold that for. avoiding insurance contracts innocent material misrepresentation is not enough; the misrepresentation must not only be material, it must be with the intent to deceive the insurer. The rule of law in contracts, generally, however, is that innocent material misrepresentation is grounds for avoidance. Therefore, those jurisdictions requiring intent to deceive in avoidance for misrepresentation impose a more onerous requirement on insurers than on contracting parties generally. It seems unreasonable then to turn about and invoke a duty of disclosure, unknown to the general contracts law, on the grounds that the insurer is a special contracting party worthy of special protection.

This leads to the natural question. If concealment is to be abolished as to forms of insurance in which no application is used, then what about those which do require applications? The interim nondisclosure area, as a practical matter, involves nothing more than misrepresentation. This has been analyzed above. In those jurisdictions requiring intent to deceive in both misrepresentation and concealment, there is no separation of concept.

The concealment notion is here really an unexplained deviation to the general rule that a representation continues down to the date of the closing of the contract. But in those jurisdictions which allow avoidance for innocent misrepresentation, but require intent to deceive in interim nondisclosure, an inconsistency arises. If the innocent misrepresentation was made in the application, such a jurisdiction avoids the policy on the grounds that the insurer was induced to contract by the applicant's

${ }^{73}$ Williakr L. Prosser, Handhook of the Law of Torts 7I4, 715 (I94x).

"MacDowell v. Fraser, I Doug. 260, 99 Eng. Rep. 170 (K. B. 1779), is the leading case. 
affirmative act; yet where the factor causing the inducement changes before the contract is closed, but after it was originally asserted, the insurer is no less induced when he closes the contract, but now the insured's conduct must have been wilful. Notice that the misrepresentation at the outset is more likely to be detected because of the physical examination and leading questions. The more logical rule would seem to be that the insurer should receive greater, not less, protection in the interim period. The underlying idea is probably that laymen, unknowing in life insurance underwriting, believe that the application and contemporaneous physical examination is the company's opportunity at them, and that where subsequent infirmity appears they were just lucky to have applied for insurance when they did. (The agent was right. They did need insurance.) Those of a more cynical bent might suggest that the dating of the policy by the insurer as of the application date for premium anniversary purposes, while coverage actually commences some weeks later, is a boldness on the part of the insurer that merits a little sympathy for the applicant. In any event, the use of the non-marine concealment rule on representations rendered untrue in the life insurance interim period in innocent material misrepresentation jurisdictions portrays a situation where putting the usual hex of uberrimae fidei on the insured operates as a hardship to the insurer.

As to interim nondisclosure where the application is made untrue, the problem is properly misrepresentation, and the results should be forged in terms of the jurisdiction's concept of representations. Where a so-called partial disclosure, which is in reality a lie or a misleading half truth, is made, the limited statement issued is a misrepresentation-an affirmation by the insured to induce the insurer to contract. Therefore, much of the present-day concealment doctrine is merely a misconception of the doctrine of misrepresentation. The majority of the courts have paid little real attention to this phase because of some similarity of results.

The only thing left to the possible operation of the doctrine of concealment would be those facts not elicited by the insurer orally or through written application. While a question can be put, "Are you now on your way to fight a duel?," it is not possible to anticipate every conceivable secret locked in an applicant's mind. Here the insurer can receive adequate protection in the normal rules of contract law without any favored treatment.

The American Law Institute Restatement of Restitution sets forth such a principle very fully: ${ }^{75}$

Fraud ... means ... non-disclosure, where it is not privileged, by any person intending or expecting thereby to cause a mistake by another to exist or to continue, in order to induce the latter to enter into or refrain from entering into a transaction.

It is elementary that where one contracting party knows that the other party is laboring under a material misapprehension which, if the mistake were mutual,

${ }^{75}$ Sec. 8(x)(c) (1937). 
would render the contract voidable, the knowing party must disclose. ${ }^{\mathbf{7 6}}$ Similarly, where the parties contract on the basis that there is a risk of the happening of an event or the existence of a condition which would affect the value of the subject matter, and one of them has knowledge of the happening or the existence of the condition, nondisclosure may render the contract voidable. ${ }^{77}$

The requisites of these rules of contract law would oblige the insurer to ask basic questions or to obtain representations in applications. There would be a substantial burden on the insurer to establish that he entered the contract under certain material conceptions with the full knowledge and the tacit encouragement of the insured. In the absence of elicited representation, the insurer could not prevail except in the case of palpable materiality. Since the sine qua non of the present majority nonmarine rule is palpable materiality, wherein the insured is felt to have had knowledge of the materiality and intended to deceive the insurer, many jurisdictions are already at the point of ordinary contractual adjudication.

In a number of the non-marine cases where the doctrine of concealment is invoked, the insurer could have learned the fact by questioning the insured. ${ }^{78}$ Those jurisdictions which apply the strict marine rule to non-marine risks, despite the fact that the insurer made no inquiry or required no application, are simply ignoring the modern social facts of the insurer-insured relationship, and instead are swamped by history.

The marine rule itself has outworn its usefulness, for in marine insurance the insurer typically requires a written application and elicits detailed information prior to the issuance of the policy. This applies to cargo as well as hull insurance. Marine insurance stands with the entire non-marine field in the complete reversal of the original reasons for the concealment rule. Similarly, because of the extensive questions put forth at the outset, most marine "nondisclosures" today are in reality misrepresentations.

The last point, and a very obvious one it is, is that in any event the naked teminology "concealment" should be abandoned. The word is intended to mean a "nondisclosure," and throughout the law "concealment" connotes a different meaning. The hygiene of legal semantics demands the removal of this misleading terminology.

\section{VIII}

\section{Conclusion}

The doctrine of concealment must be excised from the law of insurance. Nondisclosures in the interim between the application for and the delivery of insurance policies rendering representations untrue, as well as deceiving partial disclosures,

${ }^{70}$ Restatexient, Restitution $\$ 8$, comment b (1937).

${ }^{77}$ Ibid.

${ }^{70}$ E.g., Bebee v. Hartford County Mutual Fire Ins. Co., 25 Conn. 51, 65 Am. Dec. 553 (1856); $c f$. German-American Ins. Co. v. Norris, roo Ky. 29, 37 S. W. 267 (1896). 
are properly misrepresentations and should be treated as such. As to nondisclosures properly called, the ordinary rules of contract law dealing with nondisclosure should be applicable to insurance contracts.

Where the four pronged non-marine rule is invoked, the after-effect is confusionjudicial reaction to the harsh marine rule smuggling in ordinary contract rules to work just results. Where the three pronged marine rule applies, injustice is promoted by the application of a rule which is acknowledged to be without its original justification, and which has little justification other than precedent.

The retention of an empty doctrine is productive only of confusion and injustice. The law does not thrive on fictions or artificial rules, nor does it grow on a multitude of unused phrases of art. The law must be as simple and straightforward as possible, reflecting the precepts of the society that it serves. 